AKRUAL 2 (2) (2011): 136-150 $e$-ISSN: 2502-6380

\title{
AKRUAL
}

Jurnal Akuntansi

http://fe.unesa.ac.id/ojs/index.php/akrl

\section{PENGEMBANGAN TEORI AKUNTANSI BERBASIS FILSAFAT ILMU}

\author{
Muntu Abdullah \\ Fakultas Ekonomi Universitas Haluoleo \\ Email: dula_abdullah@gmail.com \\ Artikel diterima: 25 Desember 2010 \\ Terakhir direvisi: 20 Februari 2011
}

\begin{abstract}
The aim of this article is to point out the function of philosophy of science as a foundation to develop accounting theory. Historically, there are some philosophy branches developed. Nowadays, one of the philosophy branches that often used to develop accounting theory is philosophy of science. Philosophy of science is often used by accounting experts to build up accounting theory. The development of accounting theory and accounting thought is overly influenced by the basic assumption that the experts normally use. Just as four paradigms of social reality: Functionalist, Interpretative, Radical Humanist and Structuralist. The classification of these thoughts is based on the research and practice accounting which are in progress. This ism is called contemporary accounting backers. In philosophy of science, a theory is constructed by using a positive preposition and a hypothesis. It starts with an observation and then via induction process, it brings out a positive preposition. Afterwards, a positive preposition and an apriori assumption process a deduction so that bring out hypothesis preposition. The next step is examine the hypothesis in order to produce a theory which can be applied as a foundation to make rules, procedures, methods in carrying out practice accounting.
\end{abstract}

Keywords: Philosophy of Science, Development Accounting Theory

\section{PENDAHULUAN}

\section{Latar Belakang}

Filsafat ilmu adalah cabang dari filsafat yang banyak digunakan sebagai pijakan untuk mengembangkan ilmu yang merupakan bagian dari epistimologi (filsafat pengetahuan) yang secara spesifik mengkaji hakekat ilmu (pengetahuan ilmiah) (Suriasumantri, 2001:33). Lebih lanjut filsafat ilmu tentu saja juga untuk mengembangkan ilmu-ilmu sosial dan ilmu-ilmu alam. Dalam hal ini filsafat ilmu merupakan jaringan cabang ilmu satu dengan lainnya sehingga ilmu pngetahuan dapat ditelusuri sampai ke induk filsafatnya.

Filsafat ilmu merupakan salah satu cabang filsafat yang telah banyak digunakan oleh pakar akuntansi untuk mengembangakan teori akuntansi. 
Perkembangan ilmu pengetahuan dan teknologi yang sangat cepat, kadang-kadang berpengaruh pada adanya kecenderungan berpikir bahwa semua masalah dapat dipecahakan dengan metode scientific. Dalam memberikan jawaban terhadap metode yang scientific, Gaffikin (1989) mengaitkannya dengan filsafat ilmu; yaitu teori scientific adalah sarana pengetahuan scientific, namun demikian analisis struktur teori scientific merupakan salah satu masalah dalam filsafat ilmu. Sejauh ilmu dipertahankan sebagai pernyataan pengetahuan akhir maka disiplin ilmu yang lain tentu menginginkan menggunakan metode scientific.

Perkembangan pemikiran dan teori akuntansi (accounting thought) sangat dipengaruhi oleh asumsi-asumsi dasar yang digunakan, di lain pihak pemikiran akuntansi juga dipengaruhi oleh cara pengklasifikasian pemikirnya. Davis et al, (1982) mengklasifikasikan berdasarkan empat images, yaitu mereka yang memperlakukan akuntansi sebagai "a historical record, a current economic reality, an system dan a commodity". Sedangkan Morgan (1980:25) menggunakan pendekatan sosiologi yang dikembangkan oleh Burrell and Morgan. Ia melihat pemikiran akuntansi dari empat paradigma realitas sosial, yaitu functionalist, interpretative, radical humanist dan radical structuralist paradigma. Pengklasifikasian pemikiran tersebut, didasarkan pada penelitian praktek akuntansi yang berjalan, aliran ini terkenal dengan sebutan pendukung aliran contemporary accounting.

Dalam mengaktualisasi filsafat ilmu (Chambers, 1977) menggunakan preposisi positive dan hipotesis yaitu diawali dengan observasi selanjutnya melalui proses induksi dihasilkan preposisi positive. Selanjutnya preposisi positif bersamasama dengan anggapan apriori dilakukan proses deduksi untuk menghasilkan preposisi hipotesis. Selanjutnya hipotesis tersebut diuji untuk menghasilkan teori yang dapat digunakan sebagai dasar untuk membuat aturan, prosedur dan sebagainya untuk praktik.

\section{KAJIAN PUSTAKA}

\section{Pengertian Ilmu}

Pengertian ilmu dari segi makna menunjuk tiga hal, yakni pengetahuan, aktivitas, dan metode. Ketiga hal itu merupakan kesatuan logis yang mesti ada secara berurutan.

Pemahaman ilmu sebagai aktivitas, metode, dan pengetahuan menurut The Liang Gie (2004:90) dapat diringkas menjadi bagan sebagai berikut:

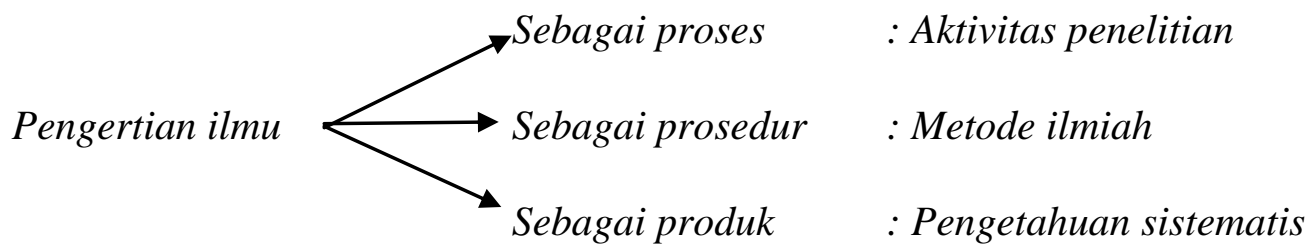




\section{Ilmu Sebagai Aktivitas Penelitian}

Ilmu secara nyata dan khas adalah suatu aktivitas manusiawi, yakni perbuatan melakukan sesuatu yang dilakukan oleh manusia. Ilmu tidak hanya satu aktivitas tunggal saja, melainkan suatu rangkaian aktivitas sehingga merupakan sebuah proses. Rangkaian aktivitas ini bersifat rasional, kognitif dan teleologis.

Tujuan yang ingin dicapai atau dilaksanakan adalah sebagai berikut: pengetahuan, kebenaran, pemahaman, penjelasan, peramalan, dan pengendalian. Penelitian sebagai suatu rangkaian aktivitas mengandung prosedur tertentu, yakni serangkaian cara dan langkah tertib yang mewujudkan pola tetap. Rangkaian cara dan langkah ini dalam dunia keilmuan disebut metode. Untuk menegaskan bidang keilmuan itu sering dipakai istilah "metode ilmiah."

\section{Ilmu Sebagai Metode Ilmiah}

Pengertian ilmu sebagai aktivitas penelitian perlu diurai lebih lanjut agar dapat dipahami. Metode ilmiah merupakan prosedur yang mencakup berbagai tindakan pikiran, pola kerja, tata langkah, dan cara tehnis untuk memperoleh pengetahuan baru atau memperkembangkan pengetahuan yang ada.

Unsur-unsur metode ilmiah adalah sebagai berikut:

1. Pola prosedural, meliputi: pengamatan, percobaan, pengukuran, survai, deduksi, induksi, analisis, dan lainnya.

2. Tata langkah, meliputi: penentuan masalah, perumusan hipotesis (bila perlu), pengumpulan data, penurunan kesimpulan, dan pengujian hasil.

3. Berbagai tehnik, meliputi: daftar pertanyaan, wawancara, perhitungan, pemanasan, dan lainnya.

4. Aneka alat, meliputi: timbangan, meteran, perapian, komputer, dan lainnya.

\section{Ilmu Sebagai Pengetahuan Sistematis}

Para filsuf dan ilmuwan sepaham bahwa ilmu terutama berupa suatu kumpulan pengetahuan yang sistematis. Ciri sistematis berarti bahwa berbagai keterangan dan data yang tersusun sebagai kumpulan pengetahuan itu mempunyai hubungan-hubungan ketergantungan dan teratur.

Ciri pokok dari ilmu, yaitu empiris, objektif, analitis, dan verifikatif (dapat diperiksa kebenarannya). Dengan memiliki pengetahuan ilmiah manusia berharap dapat membuat ramalan tentang peristiwa mendatang dan menerangkan atau menguasai alam sekelilingnya.

Jadi, ilmu adalah rangkaian aktivitas manusia yang rasional dan kognitif dengan berbagai metode berupa aneka prosedur dan tata langkah sehingga menghasilkan kumpulan pengetahuan yang sistematis mengenai gejala-gejala kealaman, kemasyarakatan, atau individu untuk tujuan mencapai kebenaran, memperoleh pemahaman, memberikan penjelasan, ataupun melakukan penerapan. 


\section{Struktur Ilmu}

Struktur pengetahuan ilmiah mencakup lima kelompok unsur, yaitu:

1. Jenis-jenis sasaran (obyek sasaran), yang meliputi: (1) Obyek material, terdiri dari: ide abstrak, benda fisis, jasad hidup, gejala rohani, peristiwa sosial, dan proses tanda; dan (2) Obyek formal, yaitu pusat perhatian.

2. Bentuk-bentuk pernyataan, meliputi: deskripsi, preskripsi, eksposisi pola, dan rekonstruksi historis.

3. Ragam-ragam proposisi, meliputi: asas ilmiah, kaidah ilmiah, dan teori ilmiah.

4. Ciri-ciri pokok, meliputi: sistematisasi, keumuman, rasionalitas, obyektifitas, verifiabilitas, dan komunalitas.

5. Pembagian sistematis.

\section{Proses Suatu Teori Berkembang}

Teori akan terus berkembang dan disempurnakan sesuai dengan pengenalan yang makin baik terhadap dunia nyata, melalui berbagai penelitian ilmiah yang dilakukan. Untuk memahami bagaimana suatu teori berkembang, Menurut Mathews dan Perera dalam Efferin dkk (2004:3), ada beberapa pendekatan, antara lain induktivisme, falsifikasi, research programes, paradikma Kuhn, dan anarkhisme.

Induktivisme, menurut induktivisme teori dapat berkembang melalui penalaran deduktif dan induktif. Pendekatan ini sering digunakan sebagai acuan dalam filsafat ilmu. Penalaran deduktif berarti berangkat dari suatu pernyataan yang bersifat umum dan dianggap benar, kemudian menjelaskan status dari sesuatu yang bersifat spesifik. Penalaran induktif berangkat dari observasi tentang sebuah fenomena yang bersifat khusus untuk menggeneralisasikan kondisinya pada suatu lingkup yang lebih besar.

Dalam penyempurnaan sebuah teori, penalaran ini digunakan untuk membentuk sebuah teori yang berawal dari pengamatan tentang sebuah fenomena spesifik. Selama pengamatan dilakukan, peneliti mengamati konsep-konsep yang terlibat, serta hubungan diantara mereka, dan melakukan generalisasi dalam konteks yang lebih luas. Pada akhirnya akan terbentuk grounded theory ( teori yang dibangun dari lapangan/kejadian sehari-hari).

Falsifikasi, menurut paham ini ilmu dan teori berkembang melalui suatu proses trial and error. Dengan demikian tidak ada istilah teori yang benar atau memiliki kebenaran. Teori yang survive tidak dikatakan benar, melainkan disebut belum dapat disalahkan. Teori dianggap berlaku (confirmed) sepanjang tidak dapat dibuktikan kesalahannya. Dengan demikian, sebuah teori akan digantikan apabila ada teori baru yang mampu membuktikan kesalahannya.

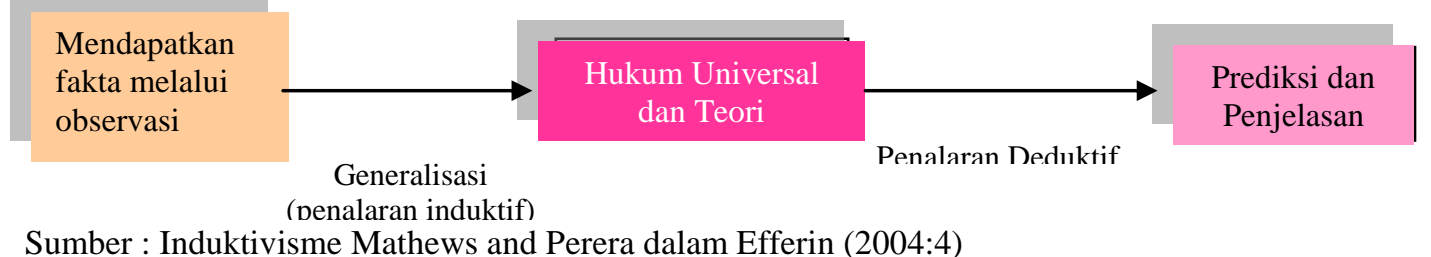

Gambar 1. Induktivisme Mathews dan Perera 
Research Programes, pendekatan ini dikemukakan oleh Lakatos. Menurut pendekatan ini teori dan ilmu akan berkembang melalui penelitian yang dilakukan. Namun Lakatos menekankan bahwa program penelitian tediri atas tiga komponen yang membentuk tiga lapisan, yaitu negative heuristic (sebagai lapisan terdalam), protective belt (lapisan tengah), dan positive heuristic (lapisan terluar).

Paradigma Kuhn, pandangan ini berasal dari Thomas Kuhn yang dikemukakan pada tahun 1970, yang mengatakan bahwa ilmu dan teori berkembang melalui rangkaian tahapan-tahapan tertentu. Ilmu (normal science) berisikan asumsi dan teori yang umum, hukum, prinsip, dan cara berpikir, dan teknik yang diterima oleh masyarakat ilmiah. Pada tahap prenormal science, hal-hal tersebut belum ada. Apabila terjadi anomali (kejanggalan) pada paradigma yang telah dianggap sebagai normal science tersebut, maka terjadilah krisis dan instabilitas yang mengarah pada terjadinya revolusi dalam bidang ilmu yang bersangkutan. Hasil revolusi tersebut adalah terbentuknya ilmu baru yang diterima sebagai normal science, demikian seterusnya.

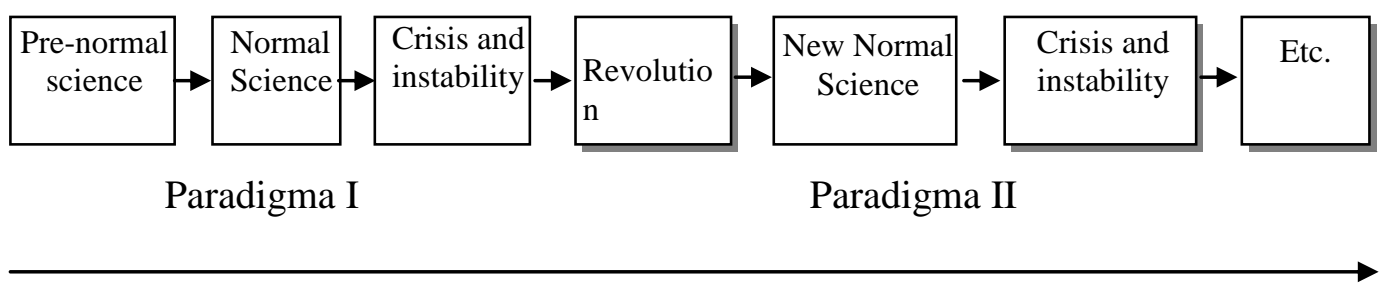

Time

Sumber: Thomas Kuhn dalam Efferin (2004:6)

\section{Gambar 2. Paradigma Kuhn}

Teori Anarki, pandangan ini dikemukakan oleh Feyerabend pada tahun 1975, yang mengklaim bahwa tidak ada satu pun pendekatan di atas yang berhasil menjelaskan secara tuntas bagaimana ilmu dan teori berkembang. Menurutnya, ilmu dan teori dapat berkembang dengan cara apa saja dengan karakteristiknya masing-masing yang khas dan berbeda-beda sesuai karakteristik dari suatu ilmu/teori. Teori itu tidak terlepas dari unsur subjektivitas penggagasnya.

\section{Pengembangan Ilmu Akuntansi}

Gaffikin (1989), dalam studinya menekankan pada metodologi untuk pengembangan akuntansi. Hal ini didasarkan pada semakain meningkatnya penelitian di bidang akuntansi, sehingga Gaffikin menganggap banyak peneliti hanya menggunakan dogma metodologi yang membabi buta. Mestinya penggunaan metodologi yang baik harus berlandaskan pada dasar-dasar filsafat. Dengan demikian 
penekanan metodologi diberikan pada argumen filsafatnya dan bukan argumen tekniknya.

Chambers (1977), dalam mengembangkan akuntansi lebih menekankan pada gabungan positivisme dan normativisme. Gaffikin (1989) menggunakan analisis sejarah yang merupakan kerangka metodologi yang lebih menarik dan menekankan pada persepsi metodologi konvensional, yaitu model konvensional dari rasionalitas secara umum. Anggapan yang digunakan Gaffikin adalah: pertama, diperlukannya investigasi terhadap epistimologi akuntansi. Hal ini diperlukan untuk mengembangkan dasar teoriktis yang baik. Untuk mencapai tujuan tersebut diperlukan investigasi terhadap karya teoritis yang nyata. Kedua, kepercayaan terhadap prinsip-prinsip yang dinyatakan oleh Laudan (1977) yaitu " tidak ada penilaian rasional yang pantas dapat dibuat tanpa pengetahuan yang kaya mengenai pengembangan sejarah." Untuk itu diperlukan investigasi bagaimana science benarbenar dipratekkan agar dapat menentukan metodologi scientific yang tepat. Hal ini sesuai dengan karya-karya para filosof keilmuan seperti Kuhn (1977), Feyerabend (1985), dan Lakatos (1970). Dengan demikian jelas bahwa, menggunakan analisis sejarah merupakan analisis terhadap karya teoritis tertentu.

\section{Peran Metodologi Dalam Pengembangan Ilmu}

Pembahasan metodologi akan dikaitkan dengan filsafat. Menurut Tejoyuwono dalam Mantra (2004:5-6), metodologi penelitian adalah susuatu ilmu tentang kerangka kerja melaksanakan penelitian yang bersistem. Fungsi filsafat adalah untuk menguji metode yang digunakan untuk menghasilkan pengetahuan yang valid. Sedangkan medologi menentukan prosedur yang digunakan baik dalam penciptaan maupun dalam pengujian preposisi untuk mendapatkan pengetahuan yang valid. Prosedur yang dijustifikasi dengan argumen filosofi, didasarkan pada pengetahuan yang diperoleh dari filsafat, sedangkan pengetahuan filsafat tersebut dihasilkan dari epistimologi dan ontologi. Epistimologi merupakan penetapan kriteria untuk mendapatkan pengetahuan yang sesungguhnya mengenai sesuatu yang riel dengan kesesuaian antara pengetahuan riel dengan konsep. Epistimologi juga menggunakan kejelian dalam operasi aktivitas scientific melalui upaya untuk mengatasi rintanganrintangan yang tidak efektif yang mengganggu produksi pengetahuan.

Ontologi adalah konsep mengenai subsistem keberadaan yaitu apa yang ada itu, Ontologi adalah ilmu intisari sesuatu hal. Metodologi yang diturunkan dari ontologi berhubungan dengan hakikat "ada" yang menjadi objek investigasi, sehingga menjawab pertanyaan "apa". Anggapan epistimologi dan ontologi adalah menjadi penentu metodologi. Belief bahwa suatu realitas itu tetap menunggu untuk ditemukan dan tidak ditemukan merupakan asumsi ontologi yang menggunakan prinsip-prinsip metodologi tertentu, sedangkan belief bahwa pengetahuan hanya didapat dari pengalaman merupakan preposisi epistimologi dari metodologi empiris, Kumala Hadi (1999). Dicontohkan secara kongkrit oleh Watts dan Zimmerman (1986) menyatakan bahwa "proposisi positive berhubungan dengan bagaimana dunia kerja" merupakan asumsi ontologi, sedangkan menyatakan anggapan bahwa "teori merupakan 
penyederhanaan realitas" merupakan anggapan epistimologi dalam membangun teori positive.

Aksiologi adalah yang mengungkap kegunaan ilmu bagi manusia. Francis Bacon menyatakan "pengetahuan adalah power", yang merupakan cerminan betapa pentingnya pengetahuan tersebut. Namun demikian kekuatan yang dimiliki pengetahuan tersebut digunakan untuk apa? Jawabannya sangat tergantung kepada manusia sebagai pemakai ilmu pengetahuan, karena ilmu pengetahuan itu sendiri bersifat netral. Bentuk umum kerangka analisis yang diresepkan dalam penelitian akuntansi menurut Kumala Hadi, (1999). pada umumnya disusun dengan urutan, (a) pernyataan masalah, (b) metodologi penelitian yang digunakan, (c) survei literatur, (d) analisa data, (e) kesimpulan.

\section{Kontribusi Filsafat Ilmu Dalam Pengembangan Ilmu}

Perkembangan pesat dalam bidang ilmu pengetahuan dan teknologi terjadi karena didukung oleh penemuan-penemuan baru yang diawali dengan percobaanpercobaan, baik lembaga pemerintah maupun swasta yang memilki kepedulian terhadap penelitian dan pengembangan. Setiap bidang ilmu pengetahuan telah memilki kepedulian terhadap penelitian dan pengembangan, dengan metode pendekatan dan cara penelitian masing-masing. Penggunaan metodologi dengan cermat dan sistematis guna menemukan informasi ilmiah maupun teknologi yang baru untuk membuktikan kebenaran hipotetis, agar dapat dirumuskan teori atau proses gejala alam atau sosial (Wahono dalam Lasiyo, 2007).

Filsafat ilmu merupakan bagian dari epistemologi yang secara spesifik mengkaji hakikat ilmu (pengetahuan ilmiah). Ilmu merupakan bagian dari pengetahuan yang menpunyai karateristik tertentu. Meskipun secara metodologi ilmu tidak membedakan antara ilmu-ilmu alam dan ilmu-ilmu sosial, namun karena permasalahan-permasalahan teknis yang bersifat khas, maka filsafat ilmu sering dibagi menjadi filsafat ilmu-ilmu alam dan filsafat ilmu-ilmu sosial termasuk di dalamnya adalah ilmu ekonomi / akuntansi.

Menurut Suriasumantri (2001:33) bahwa filsafat ilmu merupakan telaahan secara filsafat yang ingin menjawab beberapa pertanyaan mengenai hakikat ilmu :(1) Objek apa yang ditelaah ilmu? Bagaimana wujud hakiki dari objek tersebut? Bagaimana hubungan antara objek tadi dengan daya tangkap manusia (seperti berpikir, merasa dan mengindera yang membuahkan pengetahuan, (2) Bagaimana proses yang memungkinkan ditimbanya pengetahuan yang berupa ilmu? Bagaimana prosedurnya? Hal-hal apa yang harus diperhatikan agar kita mendapatkan pengetahuan yang benar? Apa yang disebut kebenaran itu sendiri? Apakah kriterianya? Cara/teknik sarana apa yang membantu kita dalam mendapatkan pengetahuan berupa ilmu? (3) Untuk apa pengetahuan berupa ilmu itu dipergunakan? Bagaimana kaitan antara cara penggunaan tersebut dengan kaidah-kaidah moral? Bagaimana penentuan objek yang ditelaah berdasarkan pilihan-pilihan moral? Bagaimana kaitan antara teknik prosedural yang merupakan operasionalisasi metode ilmiah dengan norma-norma moral profesional. 
Untuk membedakan jenis pengetahuan yang satu dengan pengetahuan lainnya maka pertanyaan yang dapat dikemukakan adalah: Apa yang dikaji oleh pengetahuan tersebut (ontologis)? Bagaimana cara mendapatkan pengetahuan tersebut (epistemologis)? Serta untuk apa pengetahuan termaksud dipergunakan (aksiologi)? Dengan mengetahui jawaban dari ketiga pertanyaan ini maka dengan mudah kita membedakan berbagai jenis pengetahuan yang terdapat dalam khasanah kehidupan manusia. Dengan begitu kita akan mudah mengenali berbagai pengetahuan yang ada seperti ilmu, seni dan agama serta menempatkan mereka pada tempatnya masingmasing yang saling memperkaya kehidupan kita. Tanpa mengetahui karateristik ilmu dengan baik, maka bukan saja tidak dapat memanfaatkan kegunaannya secara oftimal namun kadang kita salah dalam menggunakannya (Suriasumantri, 2001:35).

\section{Pendekatan Ontologi.}

Pendekatan ontologi biasa juga disebut pendekatan metafisis yang membicarakan objek ilmu, hubungan subjek dan subjek. Pada saat manusia berusaha untuk menjawab objek ilmu, objek ilmu meliputi objek material (subject matter) dan objek formal (focus of interest).

Dari segi objek material, maka dapat dibedakan menjadi dua yaitu objek kongkret dan abstrak. Dari perbedaan objek material ilmu tersebut, maka melahirkan dua faham dalam metafisik yaitu faham realisme dan idealisme. Faham realisme menitik beratkan pada kenyataan dalam ojektivitasnya oleh karena itu hakekat yang ada adalah materi atau benda. Kenyataan kongkret dapat diketahui atau dipahami melalui indera manusia. Sebaliknya idealisme berpandangan bahwa kenyataan yang sesungguhnya adalah bersifat rokhani atau kejiwaan, oleh karena bersifat abstrak yang dapat dipahami melalui persepsi mental berupa kegiatan berpikir, nalar maupun intuisi. Landasan metafisis ilmu terletak pada objek, apakah objek itu bersifat konkret ataukan bersifat abstrak. Objek ilmu juga berpengaruh pada subjek untuk menentukan metode apa yang digunakan untuk memahaminya.

Pendekatan metafisika memiliki peranan dalam perkembangan ilmu pengetahuan dan teknologi memberikan kontribusi antara lain karena metafisika : (1) mengajarkan cara bepikir cemat dan tidak lelah untuk menjawab persoalan-persoalan yang bersifat teka-teki, (2) adanya tuntutan orisinalitas berpikir untuk mengupayakan penemuan-penemuan baru maupun untuk menguji kebenaran-kebenaran yang pernah ditemukan, (3) memberikan bahan pertimbangan dan pijakan yang kuat terutama dalam praanggapan, (4) memberikan ruang pada perbedaan visi dalam memahami realitas, sehingga dapat menghargai perbedaan pandangan yang muncul dalam mencari solusi problematika (Rizal dalam Lasiyo, 2007: 2). 


\section{Pendekatan Epistemologis (Theory of knowledge)}

Setiap pengetahuan memiliki ciri-ciri yang spesifik mengenai apa (ontologi), bagaimana (epistemologi) dan untuk apa (aksiologi) pengetahuan itu disusun. Ketiga landasan ini saling berkaitan satu sama lain, jadi ontologi ilmu terkait dengan epistemology ilmu dan epistemologi ilmu terkait dengan aksiologi dan seterusnya. Jadi bila kita ingin membahas epistemologi ilmu, maka harus dikaitkan dengan ontologi dan aksiologi ilmu (Suriasumantri, 2001:105)

Inti pendekatan epistemologi adalah mempersoalkan bagaimana proses terjadinya ilmu pengetahuan, termasuk didalamnya sarana ilmiah, sikap ilmiah, metode, kebenaran ilmiah. Pemikiran merupakan landasan utama dalam melakukan kegiatan ilmiah yan akan menggabungkan kemampuan akal dengan pengalaman dan data yang diperoleh selama melakukan kegiatan ilmiah.

Dalan hubungan ini muncul dua faham yaitu faham Rasionalisme dan Empirisme. Faham Rasionalisme menekankan pada peranan akal dalam menperoleh pengetahuan. Faham ini berpandangan bahwa sumber pengetahuan manusia adalah akal atau rasio. Ilmu pengetahuan yang memenuhi syarat adalah yang diperoleh melalui kegiatan akal. Adapun ciri-ciri pokok faham Rasionalisme yaitu: (1) Adanya pendirian bahwa kebenaran yang hakiki itu secara langsung dapat diperoleh dengan menggunakan akal sebagai sarananya, (2). Adanya suatu penjabaran secara logis atau deduksi yang dimaksudkan untuk memberikan pembuktian seketat mungkin mengenai seluruh sisi bidang pengetahuan berdasarkan atas apa yang dianggap sebagai kebenaran-kebenaran hakiki tersebut di atas ( Koento Wibisono dan Misnal munir dalam Lasiyo, 2007:2). Faham rasionalisme berasal dari faham idealisme, faham ini menggunakan metode deduktif, akal, apriori dan koherensi. Adapun faham yang menekankan pada pengalaman sebagai sumber pengetahuan manusia dinamakan faham Empirisme, faham ini berpandangan bahwa pengalaman manusia meliputi penglaman lahir yang menyangkut dunia dan pengalaman batin yang menyangkut pribadi manusia. Faham empirisme bersumber dari faham realisme yang menggunakan metode induktif dalam mencari kebenaran ilmiah. Kedua faham ini, tampak perbedaan yang sangat mencolok, sehingga ada usaha untuk menpersatukan kedua pandangan tersebut, maka muncul faham Kritisme yang dipelopori oleh Immanuel Kant. Faham kritisme berpandangan bahwa pengetahuan pada dasarnya adalah hasil yang diperoleh adanya kerjasama antara bahan-bahan yang bersifat pengalaman inderawi yang kemudia diolah oleh akal sehingga terdapat hubungan sebab akibat. Kebenaran ilmiah memerlukan data dan fakta yang akurat kemudian diolah dengan metode ilmiah atau metodologi yang digambarkan sebagai the rule of the game dalam ilmu yang pada dasarnya tidak pernah berakhir (Popper, 1983:103).

Manusia dalam mengembangkan ilmu pengetahuan memilki sarana berpikir ilmiah yang meliputi: logika, matematika, statistika dan bahasa. Logika sering diartikan sebagai pengetahuan tentang kaidah berpikir atau yang berusaha untuk menarik simpulan melallui kaidah-kaidah formal yang absah. Logika menpelajari argumen, yakni wacana yang terdiri atas pernyataan simpulan yang ditarik dari dua 
atau lebih pernyataan lain yang disebut premis (Adjat Sakri dalam Lasiyo, 2007: 4). Logika dapat diartikan sebagai pertimbangan akal atau pikiran yang yang diutarakan lewat kata yang dinyatakan dalam bahasa, dengan logika manusia bernalar. Penalaran (reasoning) ialah proses pengambilan simpulan (conclusion, inference) dari bahan bukti atau petunjuk (evidence) ataupun yang dianggap bahan bukti atau petunjuk (Anton M. Moeliono dalam Lasiyo, 2007: 4).

Matematika adalah merupakan bahasa artifisial yang bersifat cermat dan terbebas dari unsur emosi. Matematika memberi sifat kuantitatif kepada pengetahuan keilmuan yang sekaligus sarana berpikir deduktif (penalaran deduktif). Penalaran deduktif merupakan suatu proses berpikir yang bertolak dari pemikiran yang bersifat umum menuju pada suatu proposisi baru yang berbentuk suatu simpulan yang bersifat khusus.

Sarana berpikir ilmiah yang ketiga adalah statistika. Statistika membantu kita dalam penarikan simpulan secara induktif dari fakta empiris. Penalaran induktif adalah penarikan kesimpulan dari yang bersifat khusus menuju kepada simpulan yang bersifat umum, penentuan kaidah umum berdasarkan hal-hal khusus.

Sarana berpikir ilmiah yang keempat adalah bahasa, dengan adanya bahasa memungkinkn manuisa berpikir secara abstrak dimana objek-objek faktual ditransformasikan menjadi simbol-simbol bahasa yang bersifat abstrak. Malalui transformasi ini maka manusia dapat berpikir mengenai sesuatu objek tertentu meskipun objek itu secara faktual tidak berada di tempat di mana kegiatan berpikir itu dilakukan. Adanya simbol bahasa yang bersifat abstrak ini memungkinkan manusia untuk memikirkan sesuatu secara berlanjut, dengan bahasa dimungkinkan untuk berpikir secra teratur dan sitematis.

\section{Pendekatan Aksiologis}

Melalui pendekatan aksiologis kita dimungkinkan untuk menjawab permasalahan menyangkut pertanyaan untuk apa pengetahuan itu? Bagaimana hubungan antara ilmu dan nilai (moral)? Inti dari pendekatan aksiologis adalah menjawab apakah manfaat ilmu pengetahuan dalam meningkatkan harkat dan martabat manusia serta pengembangan ilmu itu sendiri. Ilmu pada umumnya dimaksudkan untuk meningkatkan harkat dan martabat manusia atau untuk memanusiakan manusia. Jawaban atas pertanyaan bagaimana hubungan antara ilmu dan nilai, masih menjadi perdebatan diantara para ahli. Pandangan pertama menyatakan bahwa ilmu untuk ilmu, dalam arti ilmu bebas nilai. Pandangan kedua menyatakan bahwa ilmu tidak bebas nilai. Dua kelompok pendapat di atas didukung oleh aliran Positivisme dan Kritik Idiologi.

Aliran positivisme memandang bahwa ilmu pengetahuan akan dapat berkembang denga pesat apabila tidak ada ikatan nilai apapun kecuali nilai ilmiah. Artinya pengembangan ilmu pengetahuan harus didasarkan atas nilai ilmiah yang mengandung arti bahwa ilmu pengertahuan itu memberikan hasil yang dipercaya, mempunyai dasar tertentu, objektif dan dapat diuji secara kritis. Sebaliknya aliran Kritik Idiologi menyatakan bahwa ilmu pengetahuan hendaknya diarahkan pada 
usaha pencapaian tujuan idiologi, karena terdapat hubungan yang erat antara ilmu dan nilai (moral). Ilmu pengetahuan yang bebas nilai akan berbahaya pada eksistensi ilmu itu sendiri dan bagi kehidupan manusia.Untuk menjembatani perbedaan kedua aliran tersebut maka muncul aliran Otonomi relasional yang menyatakan bahwa ilmu seharusnya tetap berkembang maju, tapi namun perlu dikaitkan dengan suatu tujuan yang memerlukan tanggung jawab, karena pada dasarnya ilmu merupakan alat bagi manusia didalam usaha memenuhi kebutuhannya. Ilmu hendaknya dapat memberikan jaminan agar tidak terjadi penyalah gunaan oleh orang-orang tidak bertanggung jawab. Ilmu berkembang secara otonom sehingga ia dapat dibedakan antara satu dengan yang lainnya.

\section{Realitas Ilmu Pengetahuan.}

Dewasa ini ilmu pengetahuan dipandang sebagai proses, produk dan paradigma etika. Sebagai suatu proses ilmu pengetahuan merupakan sebuah kegiatan sosial dalam rangka memahami alam semesta beserta isinya, baik sebagaimana adanya maupun seharusnya. Sebagai suatu produk mengandung arti bahwa ilmu pengetahuan diperoleh/dihasilkan melalui metodologi keilmuan yang menjadi milik umum sehingga hasilnya dapat berupa rumusan-rumusan atau pernyataan-pernyataan yang perlu mendapat persetujuan masyarakat ilmiah dan kebenarannya terbuka untuk dilakukan pengujian. Sebagai paradigma etika berarti bahwa ilmu pengetahuan memilki seperangkat nilai yang meliputi universialisme, komunalisme, disinterestedness dan skeptisme yang terorganisir. Hal ini mengandung makna bahwa ilmu pengretahuan tidak begitu saja menerima kebenaran akan tetapi perlu dilakukan pengujian dan pengkajian.

Berdasarkan pada uraian tersebut, maka dalam pengembangan ilmu /teori akuntansi seyogiyanya mengacu pada pendekatan metafisis, epistemologis dan aksiologis untuk mencari jawaban terhadap persoalan pengembangan ilmu dan memberikan landasan yang bagi eksistensi ilmu pengetahuan itu sendiri. Tak dapat dipungkiri bahwa masyarakat mengalami perubahan yang dinamis yang selalu memunculkan persoalan-persoalan baru yang merupakan tantangan dan peluang bagi pengembangan ilmu pengetahuan. Untuk lebih jelasnya mengenai hal ini maka dapat disimak pada gambar berikut.

Usaha untuk menemukan ilmu pengetahuan yang baru harus mengacu pada filsafat ilmu yang didalamnya ada tiga pendekatan yaitu: (1) Pendekatan metafisis yang mengkaji apa objek ilmu? dan apa hakekat pengetahuan?. (2). Pendekatan epistemologis yang mengkaji metodologi keilmuan atau langkah-langkah ilmiah dalam menemukan ilmu pengetahuan baru yang dapat dipertanggung jawabkan kebenarannya secara ilmiah. (3).Pendekatan aksiologis yang mengkaji manfaat ilmu pengetahuan baru terhadap kemaslahatan umat manusia, bangsa dan negara sesuai dengan etika dan moral yang berkembang dalam masyarakat suatu bangsa. 
Apabila ilmu pengetahuan baru tersebut sangat bermanfaat pada usaha memanusiakan manusia, bangsa dan negara, maka ilmu pengetahuan tersebut dapat diterima sebagai teori baru yang dapat diterapkan dan dikembangkan secara terus menerus. Berikut ini disajikan skema pengembangan ilmu pengetahuan.

\section{Problem-Problem dalam Filsafat Ilmu}

Problem-problem filsafat bilamana digolongkan ternyata berkisar pada enam hal pokok, yaitu: pengetahuan, keberadaan, metode, penyimpulan, moralitas, dan keindahan. Berdasarkan enam sasaran itu, bidang filsafat dapat secara sistematis dibagi dalam enam cabang pokok, yaitu epistemology (teori pengetahuan), metafisika (teori mengenai apa yang ada), metodologi (studi tentang metode), logika (teori penyimpulan), etika (ajaran moralitas), dan estetika (teori keindahan).

Oleh karena filsafat ilmu merupakan suatu bagian dari filsafat, problemproblem dalam filsafat ilmu secara sistematis juga dapat digolong-golongkan menjadi enam kelompok sesuai dengan cabang-cabang pokok filsafat itu, yaitu: 1) Problemproblem epistemologis tentang ilmu; 2) Problem-problem metafisis tentang ilmu; 3) Problem-problem metodologis tentang ilmu; 4) Problem-problem logis tentang ilmu; 5) Problem-problem etis tentang ilmu; 6) Problem-problem estetis tentang ilmu. 


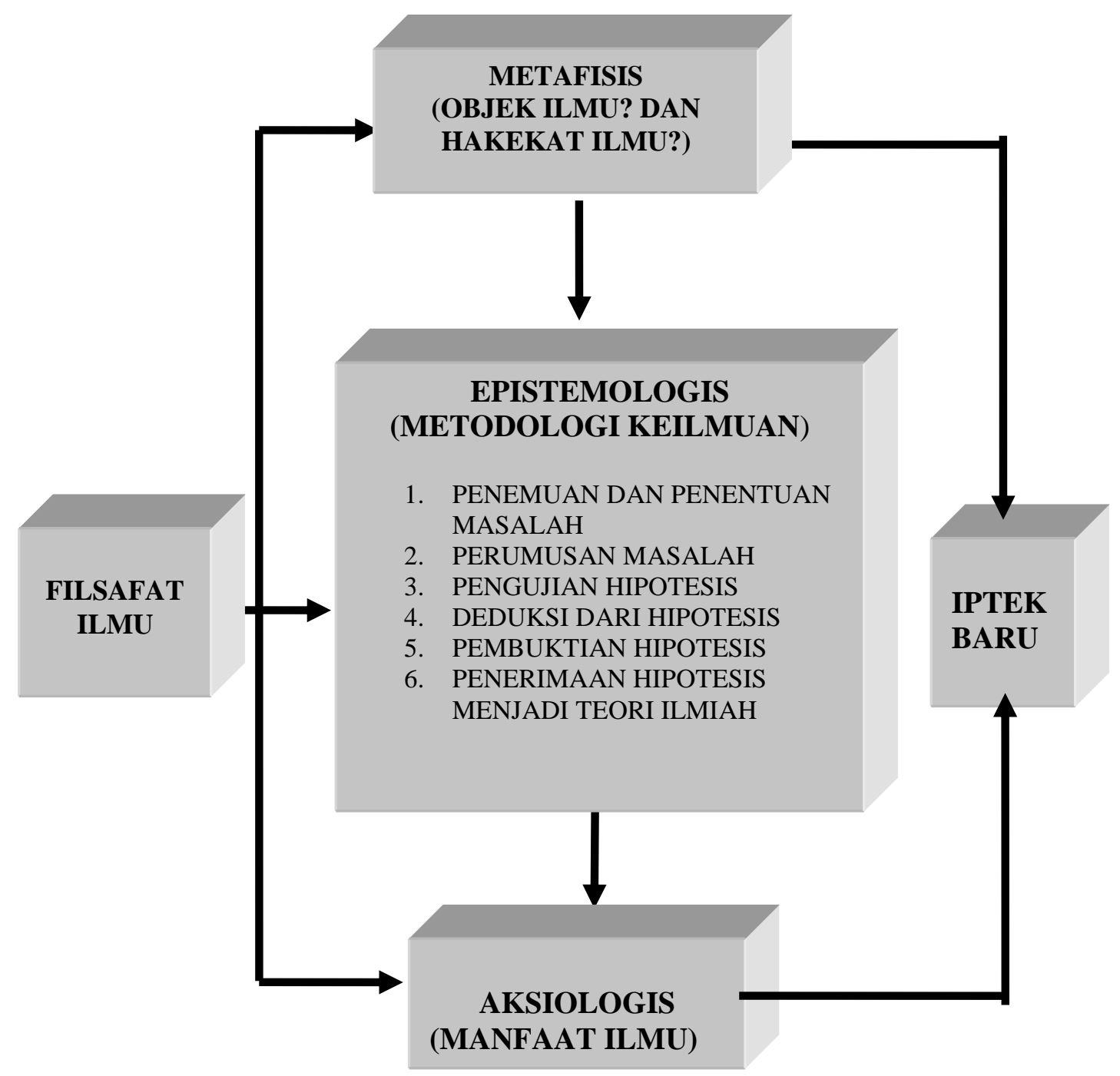

Gambar 3. I andasan Pengemhangan Ilmu

\section{SIMPULAN}

Filsafat ilmu merupakan cabang Filsafat yang telah banyak digunakan oleh ahli ekonomi dan akuntansi untuk mengembangkan baik ilmu ekonomi maupun ilmu akuntansi. Pada awalnya mengembangkan teori akuntansi didasarkan pada praktek. Seiring dengan perkembangan tuntutan bisnis terhadap akuntansi, selanjutnya teori akuntansi dikembangkan dengan pendekatan normatif descriptif. Dalam filsafat ilmu teori dibangun dengan menggunakan preposisi positive dan hipotesis yaitu diawali dengan observasi selanjutnya melalui proses induksi dihasilkan preposisi positive. 
Selanjutnya preposisi positif bersama-sama dengan anggapan apriori dilakukan proses deduksi untuk menghasilkan preposisi hipotesis. Selanjutnya hipotesis tersebut diuji untuk menghasilkan teori yang dapat digunakan sebagai dasar untuk membuat aturan, prosedur, metode dan sebagainya untuk digunakan dalam praktek. Mestinya teori akuntansi dibangun berdasarkan pada prosedur seperti ini, sehingga kita tidak berdebat pada aspek teknis akuntansi, namun harus dipandang dalam spektrum yang lebih luas yaitu pada landasan filsafati yang digunakan oleh teoari akuntansi. 


\section{DAFTAR PUSTAKA}

Chambers, F.J. 1977, “ Current Value Accounting-CoCoA or REPCO” The Singapore Accountant.

Davis,S.W., K. Menon and G. Morgan, 1982, The Images Thet have shaped Accounting theory, Accounting, Organization and Society pp 307-318.

Efferin Sujoko, Darmadji Hadi, Tan Yulianti, 2004, Metode Penelitian untuk Akuntansi: Sebuah Pendekatan Praktis, Bayumedia Publishing, Malang, Jatim.

Feyerabend, Paul. K., 1985, "Essays in Accounting". American Accounting associeation, Vol. 1

Gaffikin, M.J.R., 1989, Accounting Methodology and the work of R.J. Chambers, New York: Garland publishing company.

Gie Liang The, 2004, Pengantar Filsafat Ilmu, Penerbit Liberty, Yogyakarta.

Hadi Kumala, 1999, Aktualisasi Filsafat Ilmu Sebagai Dasar Dan Arah Pengembangan Ilmu Akuntansi, JAAI Volume 3, No. 1

Kuhn, Thomas S., 1977, The Structure of Scientific Revolution" Second Edition,University of Chicago Press.

Lakatos, Imre,.1970 "Falsification and Methodology of Scientific Research Programms".In Lakatos and Musgrav.

Laudan, Larry, 1977. "Progress and Its Problems: Towards a Theory of Scientific Growth", University California Press.

Lasiyo, 2007. Filsafat Ilmu Pengetahuan, Handout Kuliah Filsafat Ilmu. Program Pascasarjana Universitas Airlangga , 2007. Dasar-Dasar Pengetahuan. Handout Kuliah Filsafat Ilmu. Program Pascasarjana Universitas Airlangga Surabaya.

Mantra Ida Bagoes, 2004. Filsafat Penelitian dan Metode Penelitian Sosial, Pustaka Pelajar.

Morgan, G., 1980, Paradigma Metaphors and Puzzle Solving in Organization Theory, Administrative Science Quarterly.

Popper, Karl R, 1983, Realism and the aim of science, Rowman and Littlefield, New Jersey.

Suriasumantri Jujun S., 2001. Filsafat ilmu Sesuai Pengantar Populer, Pustaka Sinar Harapan, Jakarta.

Watts, Ross L. And Zimmerman, Jerold L., 1986. Positive Accounting Theory, New Jersey : Printice Hall 